\title{
A Roadmap for Exploration and Exploitation of Mineral Raw Materials in Greece ${ }^{\dagger}$
}

\author{
Diamantoula Lampou ${ }^{1, *}$, Charalambos Karathanasis ${ }^{2}$, Ioannis G. Zafeiratos ${ }^{3}$ and Petros G. Tzeferis 4 \\ 1 Directorate of Policies and Development, DG of Mineral Raw Materials, Ministry of Environment and Energy, \\ GR 11526 Athens, Greece \\ 2 Directorate of Environmental Licensing, DG of Environmental Policy, Ministry of Environment and Energy, \\ GR 11526 Athens, Greece; ch.karathanasis@prv.ypeka.gr \\ 3 Directorate of Metallic, Energy and Industrial Minerals, DG of Mineral Raw Materials, Ministry of \\ Environment and Energy, GR 11526 Athens, Greece; zafiratos.j@prv.ypeka.gr \\ 4 DG of Mineral Raw Materials, Ministry of Environment and Energy, GR 11526 Athens, Greece; \\ tzeferisp@prv.ypeka.gr \\ * Correspondence: lampou.m@prv.ypeka.gr \\ + Presented at International Conference on Raw Materials and Circular Economy, Athens, Greece, \\ 5-9 September 2021
}

check for

updates

Citation: Lampou, D.; Karathanasis, C.; Zafeiratos, I.G.; Tzeferis, P.G. A

Roadmap for Exploration and

Exploitation of Mineral Raw

Materials in Greece. Mater. Proc. 2021,

5, 80. https://doi.org/10.3390/

materproc2021005080

Academic Editor: Evangelos Tzamos

Published: 13 December 2021

Publisher's Note: MDPI stays neutral with regard to jurisdictional claims in published maps and institutional affiliations.

Copyright: (c) 2021 by the authors. Licensee MDPI, Basel, Switzerland. This article is an open access article distributed under the terms and conditions of the Creative Commons Attribution (CC BY) license (https:// creativecommons.org/licenses/by/ $4.0 /)$.
Abstract: Despite EU climate objectives and raw material needs, there is a growing concern caused by the limited direct access to primary sources and supplies of valuable raw materials, and by the heavy reliance on imports. Member states are encouraged to design and implement effective policies to improve domestic access to raw materials and to promote green energy, thus advancing European competitiveness, particularly for high tech products, emerging innovations and quality of life. The Greek Ministry of Environment and Energy, Secretariat-General for Energy and Mineral Raw Materials (MRM), Directorate-General for MRM, as an important stakeholder in the management of the raw material value chain that focuses on developing and providing a transparent and stable regulatory framework for mining and quarrying exploration and exploitation, ensures its efficient implementation in line with the principle of sustainability and facilitates strategic investments in knowledge, technology and innovation, therefore enhancing development benefits to local communities and society more generally.

Keywords: raw materials; Greece; mineral resources; regulatory roadmap

\section{Introduction}

The permitting system for mineral exploration and exploitation in Greece consists of two regulatory pillars, based on mineral raw materials categories. In this regard, the Mining Code applies to the permitting of all types of metalliferous ores except of those that are State-owned or covered by the Quarrying Law, which in turn applies to quarried raw materials such as marble, industrial minerals and aggregates in accordance with the Environmental Protection Act, setting up the existing legal regime. Field operations are managed through the Regulation on Mining and Quarrying Works.

Since governance couples minerals legislation, competent authorities and permitting/auditing regimes, it could either encourage or hinder investments in mining. Factors that may affect the investment perspective could be ascribed to a plethora of intervening competent authorities, lengthy or even indeterminable permitting timeframes, nonstandard requirements and reporting, and lack of updated information regarding mining potential.

This article presents a roadmap related to the processes required for current and future mineral resource investments and granting of permits in Greece. It contains information about the mining opportunities for critical raw materials and clarifies the procedures defined by law, and thereby facilitates decision making processes. 
This roadmap could act as a useful informative tool for both the raw materials community and the public.

\section{Greece's Present Extractive Activity and Future Mining Opportunities}

The mining industry constitutes an important factor in the economic development of the country, since it accounts for almost 3\% of the GDP [1]. The sector supplies essential raw materials for primary industries such as cement, energy, non-ferrous metals, the EU stainless steel industry, etc. The estimated sales of the country's mineral industry including domestic processing industries totals almost EUR 1.8 billion [2]. In terms of employment, the industry provides approximately 11,300 direct jobs in mines, quarries and in one out of two metallurgical plants [2]. Since extraction and processing of raw materials take place within the region in which the deposits are found, the mining industry contributes considerably to local and regional growth and development.

Greece is a major global producer of several key minerals, notably perlite (of which Greece is the second-largest producer worldwide), bentonite (4th), magnesite (8th), and bauxite (15th) [3], as shown in Table 1; their spatial distribution is shown in Figure 1. Greece is the world leader in production of ferronickel, and 5th within the EU in aluminium and alumina production, under a fully vertical integrated process.

Table 1. Greece's main non-energy mineral mining sites, industrial minerals, and marble quarries, 2019 [2].

\begin{tabular}{ccc}
\hline $\begin{array}{c}\text { Region } \\
\text { (Regional Unit) }\end{array}$ & Key Mineral & $\begin{array}{c}\text { Personnel } \\
\text { (Direct) }\end{array}$ \\
\hline $\begin{array}{c}\text { Central Greece (Fokida) } \\
\text { Central Greece (Fthiotida) } \\
\text { Central Greece (Viotia) }\end{array}$ & $\begin{array}{c}\text { Bauxite } \\
\text { Laterite, Magnesite } \\
\text { Laterite }\end{array}$ & \\
Wentral Greece (Evia) & Laterite (facility included) & 6914 \\
(Kastoria) & Magnesite & \\
Western Macedonia & Laterite & \\
(Kozani, Grevena) & Chromite, Olivinite & \\
Central Macedonia (Chalkidiki) & Pb, Zn Sulphides \\
South Aegean & Magnesite & \\
(Milos island) & Perlite, Bentonite & \\
South Aegean & Pumice, Pozzolan & \\
(Giali island) & Marble & \\
Eastern Macedonia \& Thrace & & \\
(Drama, Thassos island, Kavala) & &
\end{tabular}

Considering the intensified effort towards achieving a set of challenges to enable Europe to become the first climate-neutral continent by 2050 at the latest, the production and supply of common and rare metals is of high priority. Energy storage, in particular Lithium ion batteries, rely on access to huge quantities of specific metals and special chemistry requirements, as shown in Figure 2.

Based on a medium-scale scenario, from the perspective of 2030 the EU would demand the additional supply of 83,000 tonnes of Cobalt, 61,000 tonnes of Lithium, 3820 tonnes of Neodymium and Dysprosium, and 196,000 tonnes of Copper in order to improve and secure its technological and industrial sovereignty in strategic sectors such as batteries, PVs, electromobility, wind power, storage and digitization [4]. 


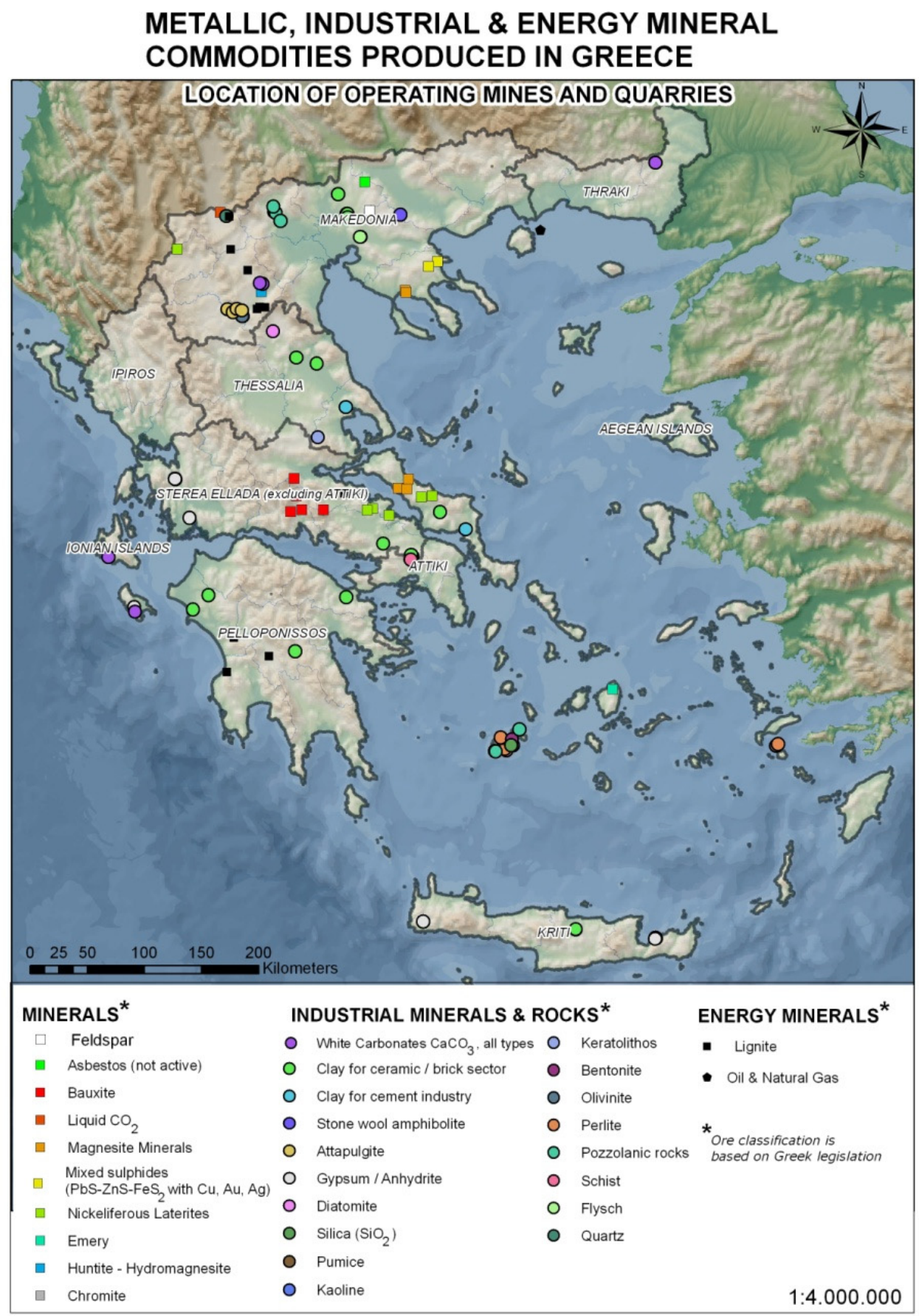

Figure 1. Metallic, Industrial and Energy Mineral Commodities produced in Greece [2].

The EU has little or no domestic primary or secondary production of all these valuable raw materials, and is heavily dependent on imports from third countries despite its promising mineral potential for developing home production, as highlighted in many national and EU-funded mineral-related projects [5]. 

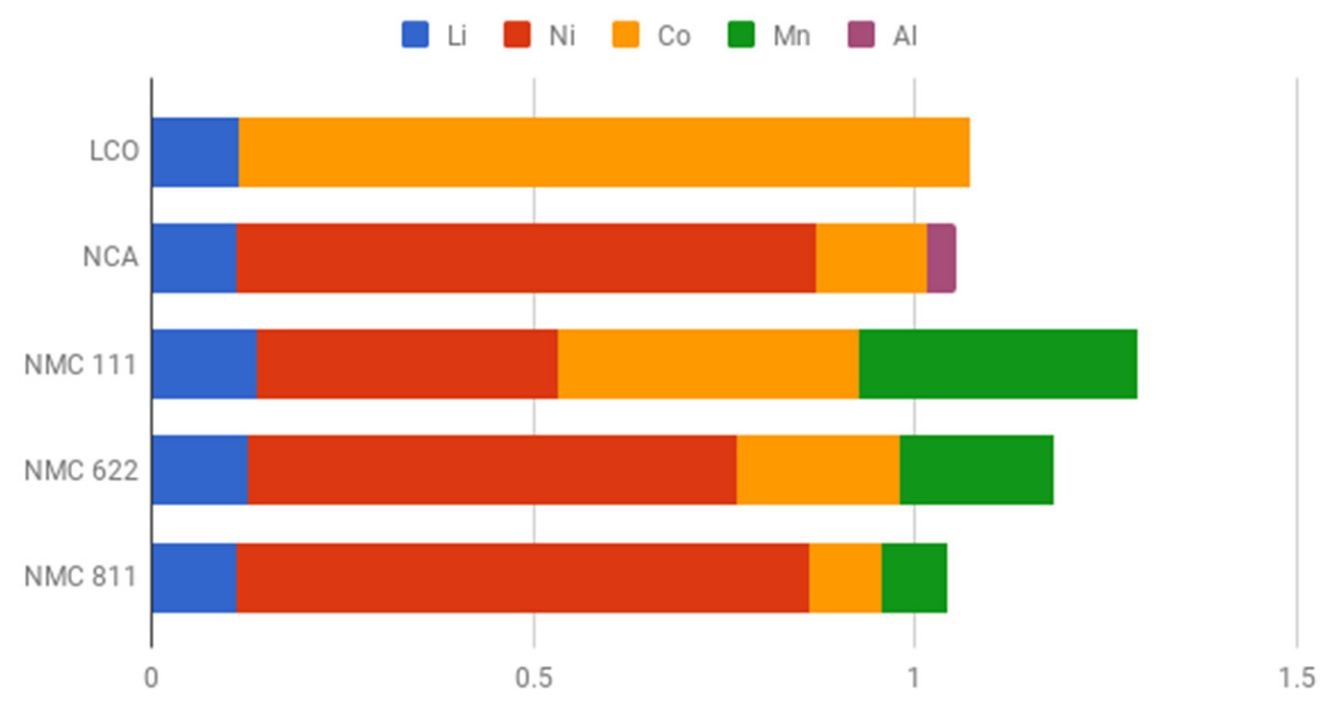

$\mathrm{kg} / \mathrm{kWh}$

Figure 2. Comparison of different battery chemistries, LCO, NCA, and NMC, and their material/elemental composition, according to [6].

Greece's mineral potential is largely contained in State-owned areas, and includes resources such as alluvial gold, stibnite, barite, bauxite (including rare earths), chromite, copper (in both oxidized and sulphide forms), dolomite, emery, feldspar and quartz (silicon), gold, graphite, hydromagnesite, huntite, iron, magnesite, manganese, mixed sulphides (iron, zinc, lead, silver), molybdenite, nickel-cobalt laterite, phosphorite (including rare earths), other rare earths, scheelite (tungsten), talc, uranium, and vermiculite. The country's large indicated reserves of some of the above minerals, shown in Table 2, are based on the Hellenic Survey of Geology and Mining Exploration estimates of selected State-owned mining areas, taking into account, however, that due to the absence of updated research the presented reserve data are not complete [7].

The above mineral raw materials include all the urgently sought-after contemporary EV battery raw materials, including nickel, cobalt and manganese. The first two metals are found in unique Greek dry nickel- and cobalt-containing laterites, which are currently being exploited only for their nickel content to produce ferronickel alloy suitable for stainless steel production [8]. The cobalt content is not produced separately, as in this case a new hydrometallurgical process would have to be introduced. The third battery metal, manganese, is not exploited today in Greece; however, there was intensive historical exploitation of battery-grade manganese for conventional lead-acid-manganese dioxidezinc battery manufacturing [9].

Other critical and equally sought-after metals and minerals, include high-purity silicon, indium, tellurium, and gallium, which are useful for microchips, photovoltaics and wind turbines, and may also be recovered in certain State Mining Areas, which are highly prospective for rare earths since their historical exploration was limited to basic and precious metals. Silicon is already being exploited in the Florina and Kozani prefectures. Full details of State Mining Areas may be obtained on demand from the Directorate of Metallic, Energy and Industrial Minerals. 
Table 2. State Mining Areas of Greece, their Prefectures, Surface Areas, Minerals and Reserves.

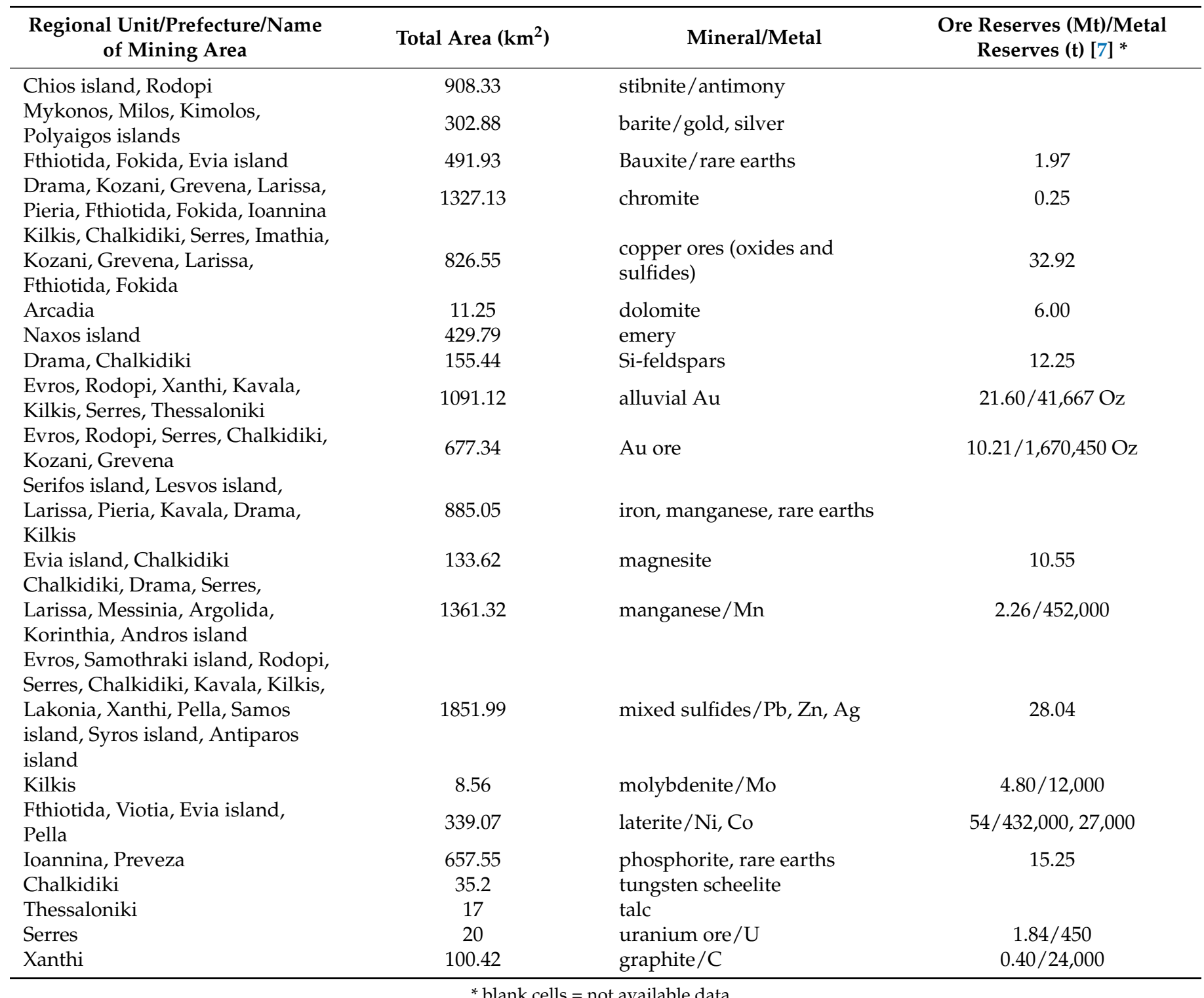

${ }^{*}$ blank cells $=$ not available data.

\section{The Legislative Framework for Mining and Quarrying Works}

\subsection{In Brie}

The Mining Code (Legislative Decree 210/1973 as amended by Law 274/1976 and later laws) governs onshore and offshore mineral exploration and development in Greece except energy minerals in liquid and gaseous forms, i.e., oil and gas, and applies to the mining of metallic minerals, metals and metallic compounds (i.e., base and precious metals), precious stones, radioactive and energy minerals (in solid form), organic sediments, and magnesite as well as some industrial minerals (i.e., feldspar, etc.,) existing either on the surface or underground. The legal characterization of a mineral as metallic is based on market economic importance rather than on scientific definition. The Mining Code regulates mineral exploration and exploitation rights, which are completely decoupled from land ownership. Taking into account that beyond state-owned minerals such as energy and radioactive minerals and the mining sites excluded in favor of the State, the right to hold a mining title can be conceded to any developer interested under the presumptions of this law.

The Quarrying Law (L.4512/2018) sets the provisions for the exploration and extraction of non-metallic minerals such as industrial minerals, marble, and other ornamental 
rocks and aggregates. Given that the relevant rights belong to the owner of the land, the Law defines the permitting framework separately for public, municipal and privatelyowned areas.

The Environmental Law (L.4014/2011 amended by L.4685/2020) defines the environmental impact assessment procedure for all kinds of economic activities, and provides for the contribution (participation in public consultation) of local communities and NGOs affected by the activity in decision making.

The Regulation of Mining and Quarrying Works defines the criteria that should be followed by developers in order to reach sustainability in all stages of a mining and quarrying project, including rules, obligations and commitments regarding the health and safety of workers and members of neighboring communities as well as environmental requirements during operation and after-care.

The Technical Study forms a vital part of the Regulation of Mining and Quarrying Works, as it evaluates the technical and economic feasibility of a whole project. It includes the exploration methods and results, the rights of land use, the exploitation plan, the economic management of the deposits, the suitable methods and best practices for mining operations, the electromechanical facilities for material processing and for the recovery of raw materials from waste, where possible, and appropriate measures regarding the safety and health of workers, local communities, and the environment. The Technical Study approval constitutes an essential mechanism which supports and promotes the principles of sustainable development.

\subsection{The Permitting (Licensing) Process}

Mineral rights may be conceded via Presidential Decree to anyone, regardless of land ownership, with the exemption of minerals (i.e., State owned minerals listed above in Section 3.1) or mining areas that are excluded in favor of the State, (Table 2). In the latter case, the State-owned mineral right can be leased through a tender procedure. The path to operation of a mining site, in addition an investor or developer's request to intend exploration (which is based on a first come-first served system and the relevant examination under the Mining Code and Environmental Law), requires several permits, as simplified and shown in Figure 3. When an exploration permit or a concession via a Presidential Decree is in force, they are subjected to an annually royalty fee system (Table 3). A leased mining site is subject to lease fees as defined in the corresponding State lease agreement.

In the case of a quarry site, the right of exploration and extraction belongs to the landowner and can be leased. The procedure to grant a quarrying site license is similar for both public and municipal lands, and starts with a developer's request to intend exploration. It is based on a first come-first served system, and the relevant examination under the Quarrying and the Environmental law requires several permits, as simplified and shown in Figure 4. Key risks in the licensing system for quarried minerals are shown in Figure 5. Regarding an operator's special duties, quarry lease agreements contain fixed and pro-rated annual lease fees. 
Exploration permit according to the Mining Code

Max area: $10 \mathrm{~km}^{2}$

Duration: 3 ys

Application Fees: $3000 €$

Competent authority: Head of Region

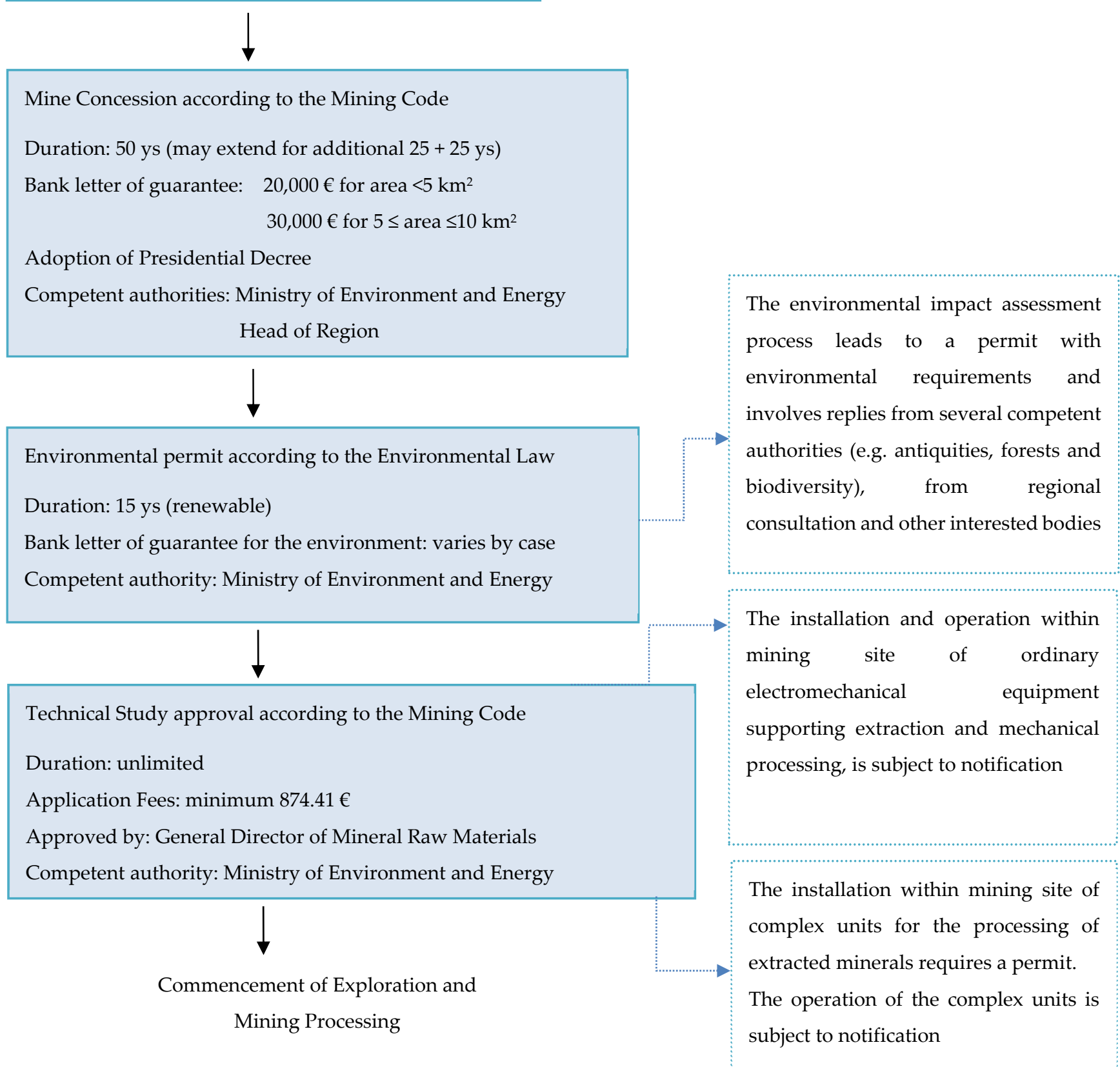

Figure 3. Permitting steps to start up a mine. 


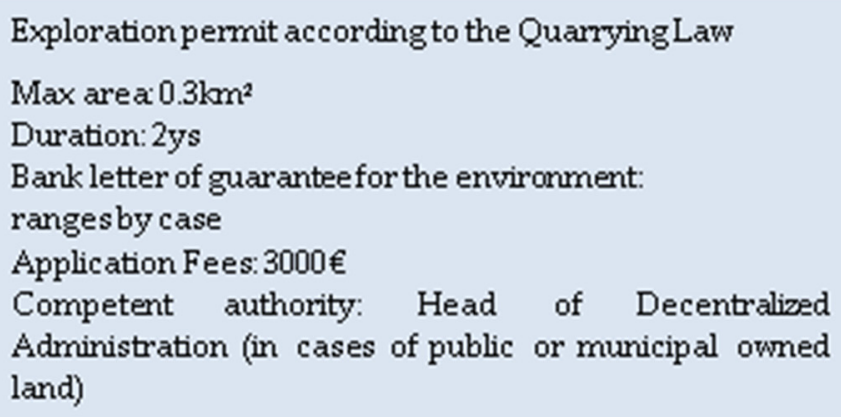

Environmental permit acconding to the Environmental Law

Duration: 15ys (renewable)

Bank letter of guarantee for the environment: ranges by case

Competent authority: Ministry of Environment and Energy

(activities classified under category Al)

Head of Decentralized Administration

(activities classified under category A2)

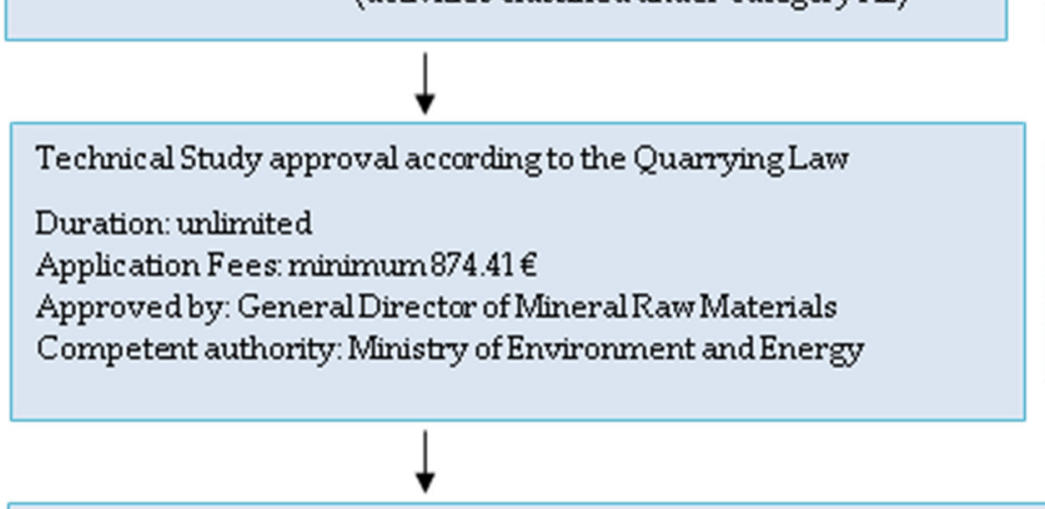

The environmental impact assessment process leads to a permit with environmental requirements and involves replies from several competent authorities (e.g. antiquities, forests and biodiversity), from regional consultation and other interested bodies

The installation and operation within the quarry site, of any kind of equipment used for the exploitation and for processing, is subject to notification

Quarry permit via directlease agreement according to the Quarrying Law

Duration:70ys

Bank letter of guaranteefor the lease: varies by case

Application Fees: $600 €$

Competent authority: Head of Decentralized Administration (in case

of public land)

The Municipality (in case of municipalland)

\section{Commencement of Exploration and Quarry Processing}

Figure 4. Permitting steps to start up a quarry.

No permit is required to conduct exploration for typical aggregates such as crushed rock or sand and gravel. Extraction of aggregates is permitted within defined Quarry Areas, which are distributed across the entire territory in order to cover regional and local construction needs. The right to extract aggregates within public or municipal Quarry Areas is gained through a tender procedure. 


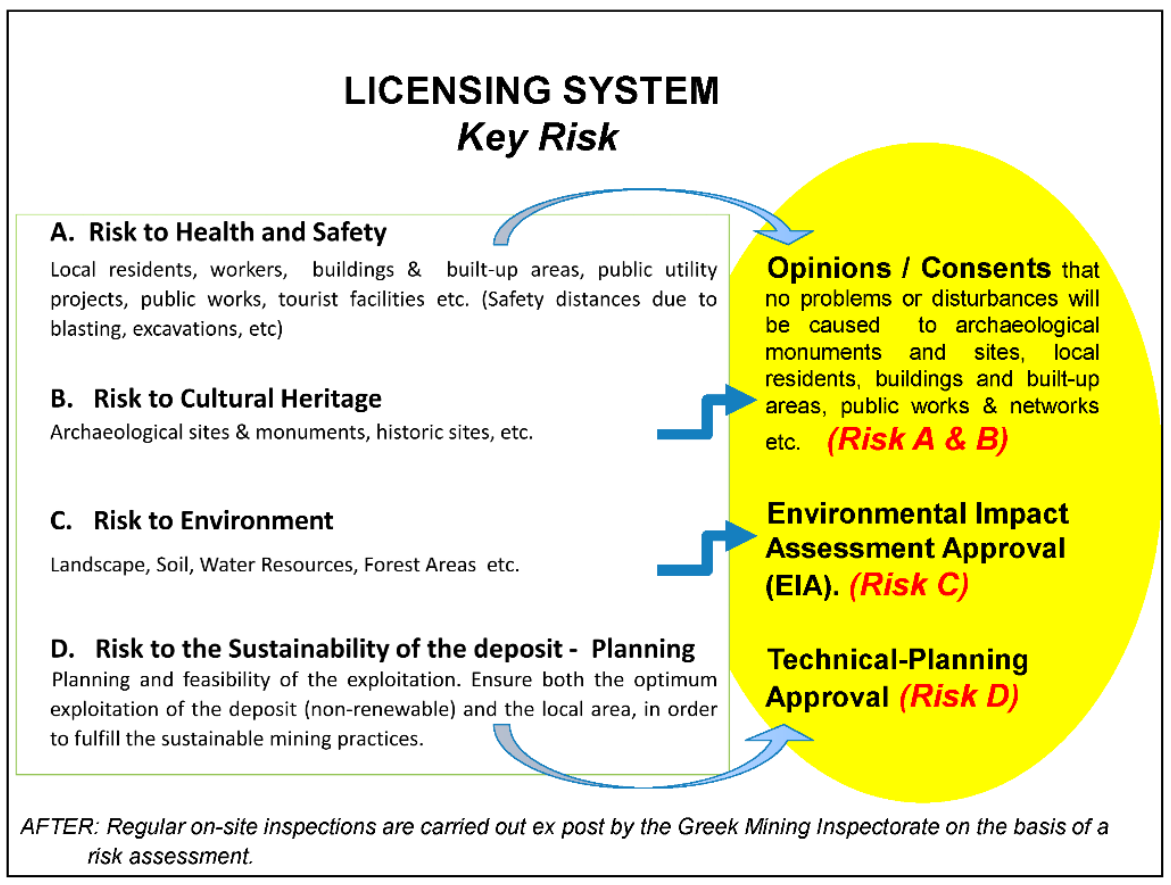

Figure 5. Key risk factors regarding the licensing system.

Table 3. Annual fees for mines and quarries.

\begin{tabular}{|c|c|}
\hline & Annual Royalty Fees \\
\hline Mining exploration permit & \multirow{2}{*}{$\begin{array}{l}\text { Royalty fees system, defined by the Joint Ministerial Decree } \\
\text { J.M.D.10697/2714/2014 (G.G. B'1800/2014) } \\
\text { Subject to Article } 176 \text { of the Mining Code and the above J.M.D, } \\
\text { the owners or exploiters of active (producing), reserve and } \\
\text { inactive Mining Concessions pay to the State an annual amount } \\
\text { of royalty. Exploration License holders also pay an annual } \\
\text { amount of fee. The amount of the fee in all cases is calculated } \\
\text { from a specific mathematical formula. }\end{array}$} \\
\hline $\begin{array}{l}\text { Mining Concession given by a } \\
\text { Presidential Decree }\end{array}$ & \\
\hline Mining Lease agreement & Fees defined in the State lease agreement \\
\hline Quarry exploration/permit & Nil \\
\hline Quarrying lease agreement & Fixed and pro-rata lease fees in case of public or municipal land \\
\hline $\begin{array}{l}\text { Special fee in favour of the } \\
\text { municipal }\end{array}$ & $\begin{array}{l}\text { a special fee depend on the selling price of aggregate materials } \\
\text { produced in the territory of the municipal }\end{array}$ \\
\hline Green fee & $\begin{array}{c}\text { a green fee equal to } 1 \% \text { of the value of the products sold for all } \\
\text { quarries operate for over } 40 \text { years }\end{array}$ \\
\hline
\end{tabular}

\subsection{The Environmental Impact Assessment Procedure}

The national legislative framework for the environmental permitting of mining and quarrying activities consists of L.4014/2011, amended by L.4685/2020 and supplemented by additional specific legislation aiming to address key environmental variables such as the management of mining waste, surface water and groundwater, the cultural environment, biodiversity and NATURA 2000 sites, forests and forest areas, major disaster risk management, and vulnerability assessments for the prevention of natural disasters. Each of the above is applied on a case-by-case basis during the development of a mining activity. For example, in an aggregate quarry where usage of the extracted rock reaches $100 \%$, regulatory measures for the management of mining waste are generally not required. 
The protection of biodiversity is a crucial issue in the environmental assessment of mining activities. In particular, when a mining activity takes place in areas of biodiversity protection (covered by the NATURA 2000 network, i.e., Special Areas of Conservation according to the NATURA Directive, the Habitats Directive, or Special Protection Area according to the Birds Directive), an adequate environmental assessment must be carried out, with the submission of a report called a special ecological assessment (SEA) within the EIA Study so as to assess the potential impacts of the mining project on the integrity and conservation objectives of the NATURA 2000 site.

An environmental permit takes place under the evaluation and authorized approval of the environmental impact assessment study (EIA); however, in the case of some exploration activities in both mines and quarries, the approval of a predefined study report called the Standard Environmental Commitments (SEC) is required instead of an EIA.

In addition, an extractive waste management plan must be drawn up and approved by the environmental authorities. The management of waste from mining and quarrying operations is regulated by the Extractive Industry Waste Regulation of 2009, adopted in transposition of the EU Directive 2006/21. A financial guarantee is also required in order for the State to secure the respect of all obligations arising from the relevant EIA and the availability of funds at any given time for the rehabilitation of the land affected by such extractive operations and waste management.

The administrative process of environmental assessment for mining activities is conducted digitally via an electronic environmental registry (EER) platform [10], as shown in Figure 6. The environmental decisions and licenses are published online in accordance with the general principles of publicity and transparency (aepo.ypeka.gr (accessed on 10 October 2018), diavgeia.gov.gr (accessed on 10 October 2018)). 


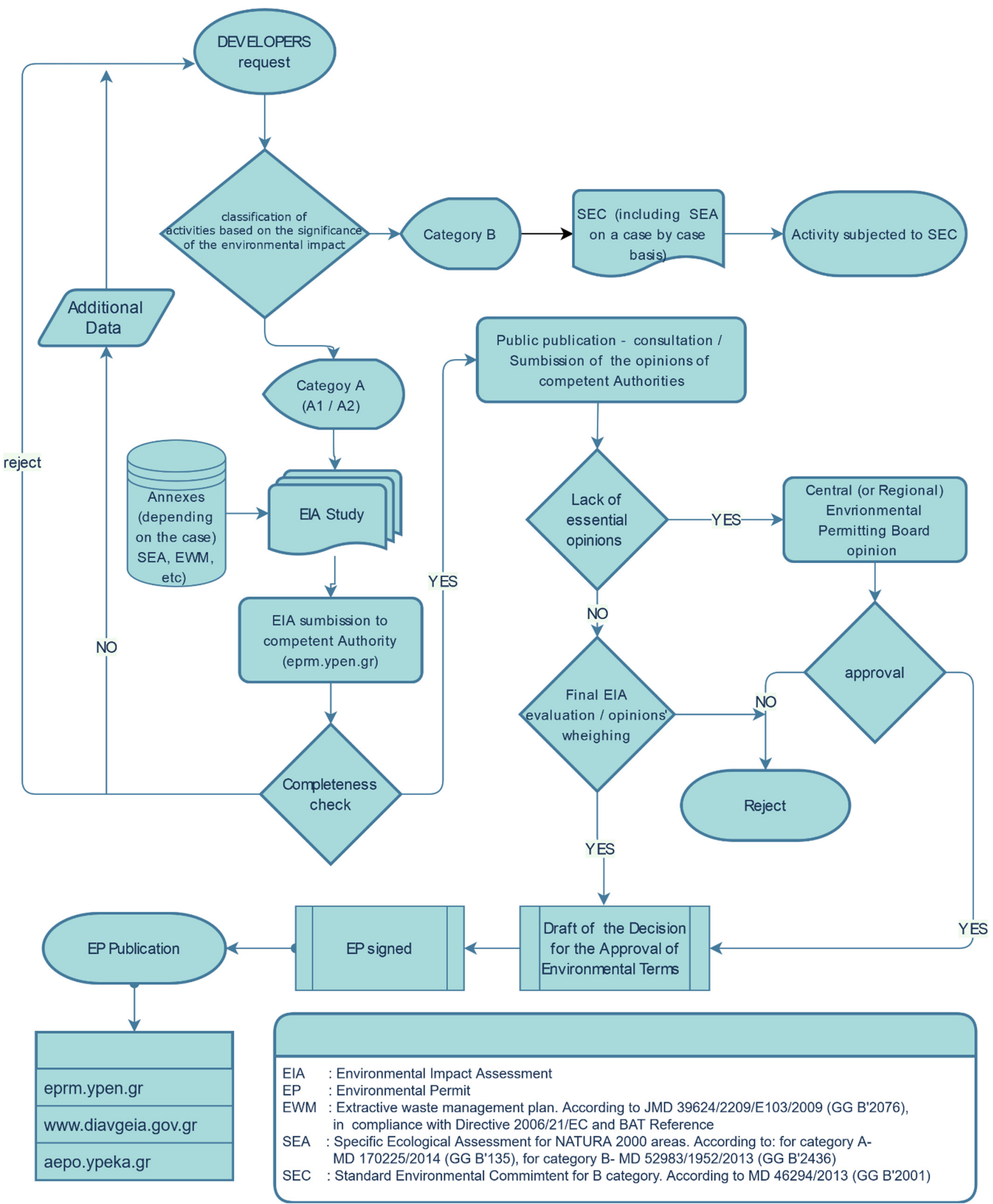

Figure 6. Environmental permitting procedure flowchart according to L.4014/2011 (as amended by L.4685/2020).

Institutional Review Board Statement: Not applicable. 


\section{References}

1. Report on Mining Industry Contribution in the Greek Economy; Foundation of Economic and Industrial Research: Athens, Greece, 2018.

2. Annual Extractive Activity Reports; Hellenic Republic, Ministry of Environment and Energy: Athens, Greece, $2018-2020$.

3. Reichl, C.; Schatz, M. Minerals Production, World Mining Data; Republic of Austria, Federal Ministry of Agriculture, Regions and Tourism: Vienna, Austria, 2020.

4. Critical Materials for Strategic Technologies and Sectors in the EU-A Foresight Study; European Commission: Luxembourg, 2020.

5. Lewicka, E.; Guzik, K.; Galos, K. On the Possibilities of Critical Raw Materials Production from the EU's Primary Sources. Resources 2021, 10, 50. [CrossRef]

6. Olivetti, E.A.; Ceder, G.; Gaustad, G.G.; Fu, X. Lithium-Ion Battery Supply Chain Considerations: Analysis of Potential Bottlenecks in Critical Metals. Joule 2017, 1, 229-243. [CrossRef]

7. Committee for the Assessment of State Owned Mining and Industrial Minerals Areas Economic and Reserves Potential; Project Report; Ministry of Environment and Energy: Athens, Greece, 2014.

8. Eliopoulos, D.G.; Economou-Eliopoulos, M. Geochemical and mineralogical characteristics of Fe-Ni- and bauxitic-laterite deposits of Greece. Ore Geol. Rev. 2000, 16, 41-58. [CrossRef]

9. 100 Years of Hellenic Geological Survey, Hellenic Survey of Geology and Mineral Exploration. 2021, pp. 160-163. Available online: https:/ / eagme.gr/static-pages/100-xronia (accessed on 1 August 2021).

10. Digital Environmental Registry. Available online: https:/ /eprm.ypen.gr/ (accessed on 10 October 2018). 